\title{
Management of Wheat Diseases
}

\author{
María Rosa Simón, ${ }^{1}$ Juan G. Annone, ${ }^{2}$ and Paul C. Struik ${ }^{3}$ \\ ${ }^{1}$ Cereals, Faculty of Agricultural and Forestry Sciences, National University of La Plata, 60 y 119. CC311900 La Plata, Argentina \\ ${ }^{2}$ National Institute of Agricultural Technology (INTA) Pergamino, Ruta 32 Km 4, 5. CC312700 Pergamino, Argentina \\ ${ }^{3}$ Centre for Crop Systems Analysis, Wageningen University, Droevendaalsesteeg 1, 6708 PB Wageningen, The Netherlands \\ Correspondence should be addressed to María Rosa Simón, mrsimon@agro.unlp.edu.ar
}

Received 7 August 2012; Accepted 7 August 2012

Copyright (C) 2012 María Rosa Simón et al. This is an open access article distributed under the Creative Commons Attribution License, which permits unrestricted use, distribution, and reproduction in any medium, provided the original work is properly cited.

Diseases can severely reduce the economic return of growing wheat. Wheat diseases cause harvest losses, affect the quality of the harvest crop, and cause storage losses. Yield losses might depend on the genetically determined resistance and tolerance of the wheat cultivars to specific diseases, the diversity and level of the pathogen inoculum present, and the environmental conditions. This special issue includes two reviews articles and four research papers addressing the structure of the population of and the location of the resistance to some pathogens, the effect of fungal diseases affecting seedlings, leaves, and spikes on wheat yield and quality, and different strategies to manage them.

Two review articles on bacterial (Pseudomonas syringae pathovars) and fungal diseases of wheat (Mycosphaerella graminicola (Fückel) Schroeter in Cohn, anamorph Septoria tritici Rob. ex Desm.) causing septoria leaf blotch are included. The first one is written by A. J. Valencia-Botin and M. E. Cisneros-López and addresses recent advances in the characterization of the population of the bacterial pathogen by traditional and molecular techniques, the evaluation of its aggressiveness, the pattern of colonization in the wheat seeds and its effects on seed yield, yield components, and source-sink relationships during the postanthesis period. The second one is written by M. R. Simón et al. and describes the most recent efforts to investigate the structure of the population of the fungal pathogen and the location of genes for resistance, with special emphasis on the work carried out in Argentina during the last years.

In addition, M. C. Quincke et al. examine the incidence of Cephalosporium stripe, caused by Cephalosporium gramineum Nikisado and Ikata, a pathogen causing a serious disease of winter wheat in the Pacific Northwest of the USA, on yield loss, test weight, kernel weight, kernel diameter, and grain protein, whereas R. P. Marano et al. assess how supplementary irrigation affects yield and the incidence and severity of some foliar diseases mainly leaf rust caused by Puccinia triticina Eriks, tan spot caused by Pyrenophora tritici-repentis (Died.) Drechs., anamorph Drechslera triticirepentis (Died.) Shoem., and septoria leaf blotch. Furthermore, I. M. Haigh and M. C. Hare describe the effect of freezing temperatures on Monographella nivalis (Schaffnit) Müller, anamorph Microdochium nivale (Fr.) Samuels, and Hallet and Monographella majus (Wollenw.) Glynn and Edwards, causing seeding blight of winter wheat, whereas $\mathrm{M}$. Nicolau and J. M. C. Fernandes present a predictive model for daily inoculum levels of Gibberella zeae (Schwein.) Petch., anamorph Fusarium graminearum Schwabe in Passo Fundo, Brazil which combined with an infection process model might be useful to quantify the impact of Fusarium head blight epidemics on wheat yield and quality.

Together these papers give insight into the diversity of approaches in investigating the control of wheat diseases. We would like to thank all contributors for their interesting contributions and hope that this compilation will be instrumental in getting abreast of some recent advances on some of the main diseases of wheat.
María Rosa Simón Juan G. Annone Paul C. Struik 


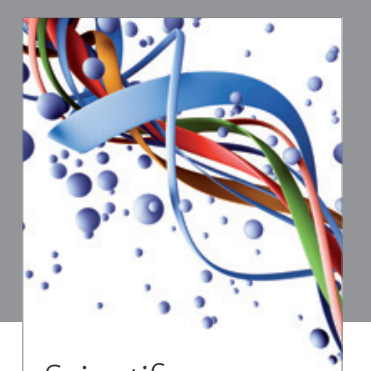

Scientifica
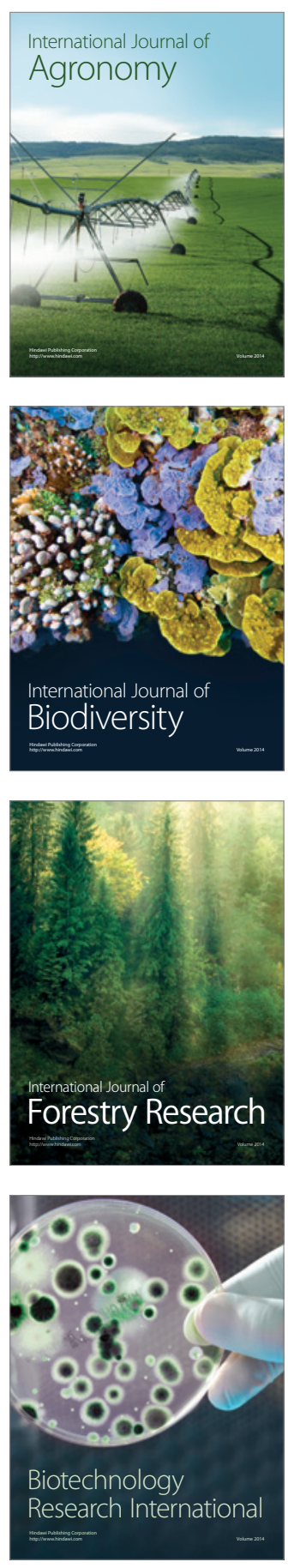
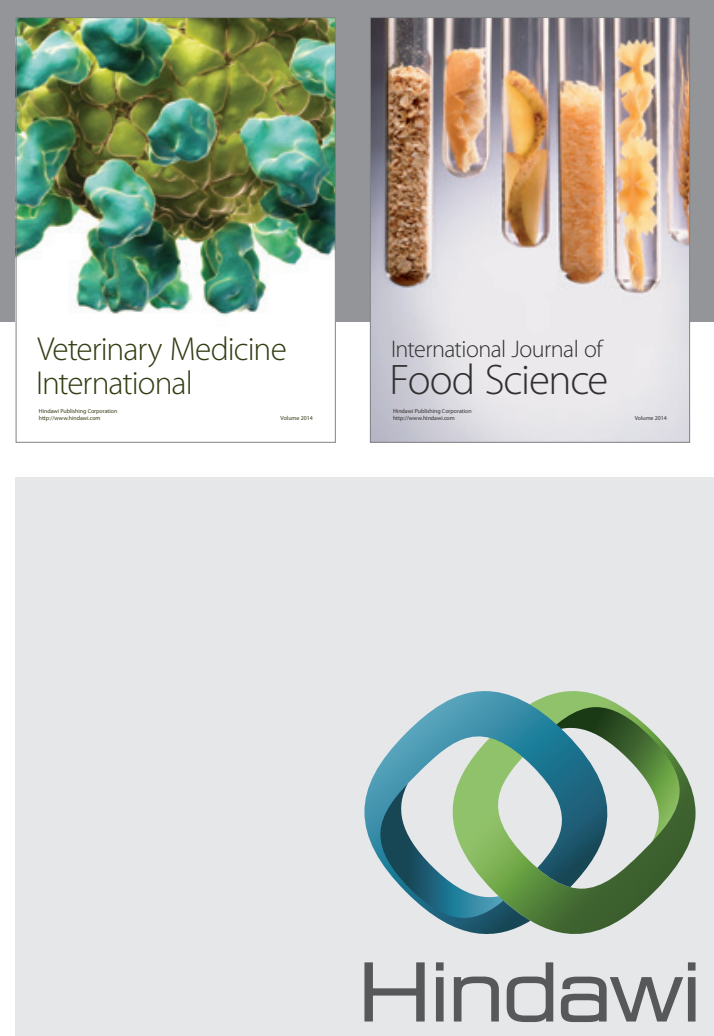

Submit your manuscripts at

http://www.hindawi.com
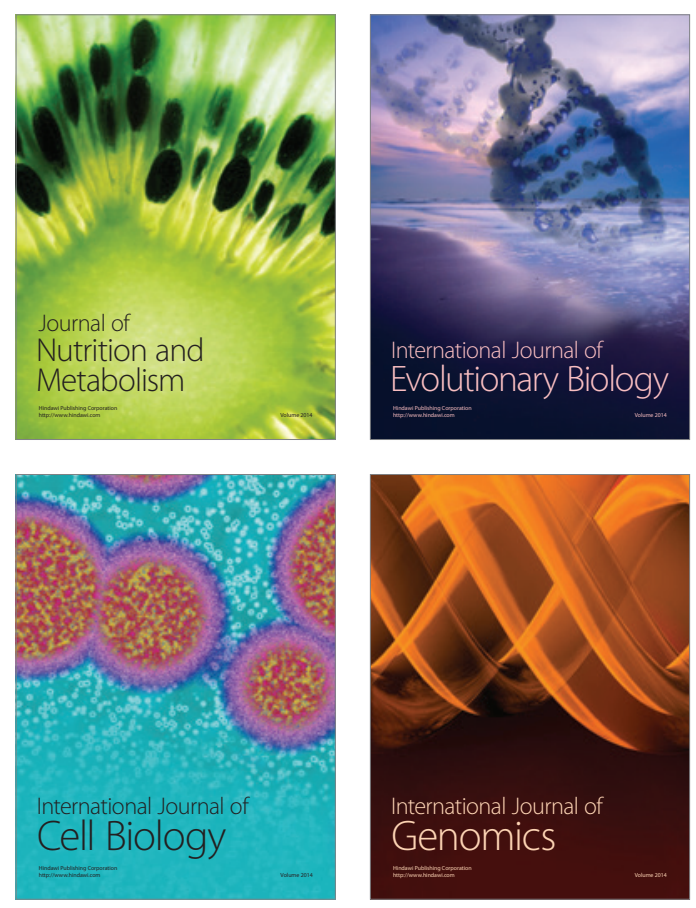
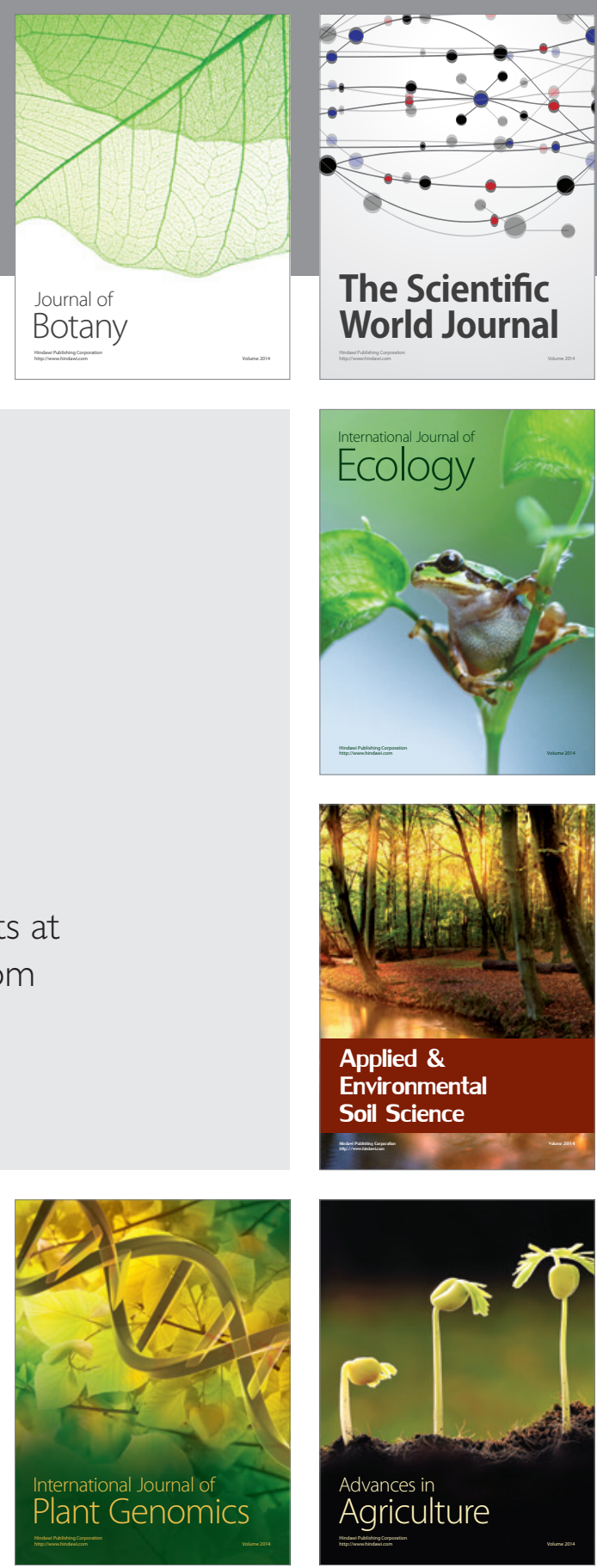

The Scientific World Journal


International Journal of Microbiology

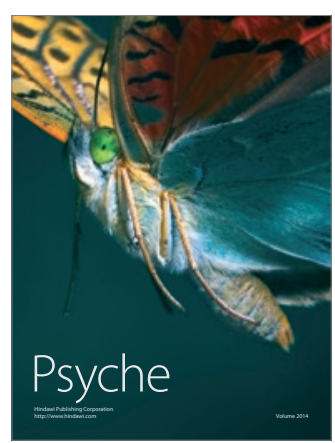

